\title{
Properties of Chitin Synthetase from Coprinus cinereus
}

\author{
By G. W. GOODAY AND ANNE DE ROUSSET-HALL \\ Department of Biochemistry, University of Aberdeen, Marischal College, Aberdeen AB9 I AS
}

(Received 23 December 1974; revised 20 February 1975)

\begin{abstract}
SUMMARY
Preparations of chitin synthetase (EC. 2.4.I.I6) from the stipe of the toadstool Coprinus cinereus were characterized. Microsomal fractions had a very high specific activity. The chitin synthetase had been solubilized by treatment with digitonin, with an increase in specific activity and in stability. Optimum conditions for enzyme activity were determined. These preparations needed only a divalent cation and UDP- $N$-acetylglucosamine for chitin synthesis and showed no primer requirement. The sole glycosyl product was characterized as macromolecular chitin.
\end{abstract}

\section{INTRODUCTION}

Chitin is the characteristic component of the walls of most filamentous fungi, where it occurs as structural microfibrils. The control of chitin biosynthesis must be of great importance during fungal growth. The enzyme which is responsible for the deposition of chitin, uridine diphosphate- $N$-acetylglucosamine:chitin $N$-acetylglucosaminyltransferase, EC. 2.4 . I . 16, 'chitin synthetase', was first characterized by Glaser \& Brown (I957) from Neurospora crassa. Here we present properties of the enzyme extracted from the stipes of Coprinus cinereus, as part of a study of the regulation of chitin deposition during differentiation in this fungus. Aspects of the development of the Coprinus fruit bodies and the major role of chitin synthetase in this process have already been described (Gooday, 1972 $a, b$, 1973, 1974). The regulation of enzyme activity by concentrations of substrate and chosen effectors is considered in detail in the following paper (de Rousset-Hall \& Gooday, 1975).

\section{METHODS}

Growth of cultures. The culture of Coprinus cinereus (Schaeff. ex Fr.) S. F. Gray (=C. lagopus sensu Buller) was that used for previous work (Gooday, 1972a, 1973, 1974), and was grown as described by Gooday (1974) with minor differences. A piece of mycelium was inoculated in the centre of $100 \mathrm{ml}$ of medium (glucose, $4 \mathrm{~g}$; yeast extract, $4 \mathrm{~g}$; malt extract, Io $\mathrm{g}$; agar, $20 \mathrm{~g}$; water, I 1 ) in a wide-mouthed $500 \mathrm{ml}$ conical flask. The cultures were incubated at $35^{\circ} \mathrm{C}$ for 4 days in the dark and then transferred to $25^{\circ} \mathrm{C}$ under a cycle of $16 \mathrm{~h}$ light to $8 \mathrm{~h}$ dark. Fruit bodies were harvested 8 to 9 days after inoculation when they were Io to $20 \mathrm{~mm}$ long. The caps were pulled off and the stipes were wiped clean of adhering mycelium.

Preparation of enzyme extracts. All procedures were carried out at $0{ }^{\circ} \mathrm{C}$. Unless otherwise stated, the particulate enzyme preparations were made from stipe tissue as described by Gooday (I973). To make the solubilized enzyme preparations, $0.7 \mathrm{~g}$ of stipes were cut into I mm slices. Homogenizing medium ( $10 \mathrm{ml}$ ) containing $50 \mathrm{~mm}$-tris- $\mathrm{HCl} \mathrm{pH} \mathrm{7.5,} 10 \mathrm{~mm}-$ $\mathrm{MgCl}_{2}, \mathrm{I} \cdot 0 \mathrm{mM}$-EDTA (disodium salt), and $250 \mathrm{~mm}$-sucrose, was added and the tissue homogenized in a Potter-Elvehjem homogenizer for I min at $6000 \mathrm{rev} . / \mathrm{min}$. The 
homogenate was centrifuged at $9000 \mathrm{~g}$ (average radius, $r_{\mathrm{av} .}, 80 \mathrm{~mm}$ ) for $20 \mathrm{~min}$ in a Sorval Superspeed $\mathrm{RC2}-\mathrm{B}$ centrifuge to remove debris and mitochondria. The resulting supernatant was centrifuged at $105400 \mathrm{~g}\left(r_{\mathrm{av}}, 59 \mathrm{~mm}\right)$ for $60 \mathrm{~min}$ in a Beckman Spinco centrifuge with a type 40 angle rotor. The pellet was mixed with $\mathrm{IO} \mathrm{ml}$ of resuspending medium (homogenizing medium without sucrose) and recentrifuged for $60 \mathrm{~min}$ at $105400 \mathrm{~g}\left(r_{\mathrm{av}}, 59 \mathrm{~mm}\right)$. The microsomal pellet was solubilized by resuspending it in $0.7 \mathrm{ml}$ resuspending medium containing $10 \mathrm{mg}$ digitonin (Sigma) $/ \mathrm{ml}$. The extract was kept at $0{ }^{\circ} \mathrm{C}$ for $30 \mathrm{~min}$ and centrifuged at $\mathrm{I} 30600 \mathrm{~g}\left(r_{\mathrm{av}}, 73 \mathrm{~mm}\right)$ for I h in a Beckman Spinco L2 centrifuge with a swing-out SW50 rotor. The supernatant was stored in the deep freeze and used as the solubilized enzyme preparation.

Protein was determined by the method of Lowry et al. (I95I) using bovine serum albumin (containing, where appropriate, the same amount of digitonin as the enzyme sample) as a standard.

Assays of enzyme activity. The reaction mixture (I $5 \mu \mathrm{l})$ contained $5 \mu \mathrm{l}$ of enzyme preparation and final concentrations of $50 \mathrm{mM}$-tris- $\mathrm{HCl} \mathrm{pH} 7.5$, Io $\mathrm{mM}_{-} \mathrm{MgCl}_{2}, \quad$ I mM-EDTA (disodium salt), $2 \mathrm{mg}$ chitodextrins (Fraction II) $/ \mathrm{ml}, 20 \mathrm{~mm}-N$-acetylglucosamine, and 0.4 mM-uridine diphosphate- $N$-acetylglucosamine (UDP-GlcNAc) containing $13.7 \mathrm{nCi}$ of UDP-[U-14 $\mathrm{C}] \mathrm{N}$-acetylglucosamine $(270 \mathrm{mCi} / \mathrm{mmol}$; The Radiochemical Centre, Amersham, Buckinghamshire). Incubations were for $5 \mathrm{~min}$ at $25^{\circ} \mathrm{C}$ in $\mathrm{I} \cdot 2 \mathrm{ml}$ conical plastic centrifuge tubes, and the reaction was stopped by immersion in a boiling-water bath for $2 \mathrm{~min}$. The chromatography of the reaction products, the autoradiography and the estimation of radioactivity were as described by Gooday (1973).

A revised assay was used for the experiments with the solubilized enzyme preparations. The medium ( $20 \mu \mathrm{l}$ ) contained $5 \mu \mathrm{l}$ of enzyme preparation (I to $2 \mu \mathrm{g}$ protein) and final concentrations of $63 \mathrm{~mm}$-tris- $\mathrm{HCl} \mathrm{pH} 7.5,12.5 \mathrm{mM}_{-1 \mathrm{MCl}_{2},}$ I.25 mM-EDTA (disodium salt), and I mM-UDP-GlcNAc containing I $2 \cdot 5 \mathrm{nCi}$ of the UDP- $\left[\mathrm{U}-{ }^{14} \mathrm{C}\right] N$-acetylglucosamine. The assay was incubated and the reaction stopped as above. The entire contents of the tube were filtered through a Millipore GS filter (pore size $0.22 \mu \mathrm{m}$ ) which had been pre-washed in $5 \%(\mathrm{w} / \mathrm{v})$ trichloracetic acid in $20 \mathrm{mM}-\mathrm{Na}_{4} \mathrm{P}_{2} \mathrm{O}_{7}$, to prevent any unreacted UDP-GlcNAc from sticking to the filter. The tube was washed three times with $20 \mu \mathrm{l} \mathrm{I} \%(\mathrm{v} / \mathrm{v})$ aqueous Triton X-I00, and the washings filtered. The filter was finally washed with $15 \mathrm{ml}$ water, and was dried at room temperature for $\mathrm{I} h$ and for a further $30 \mathrm{~min}$ at $110^{\circ} \mathrm{C}$. This filtration procedure, which we assume relies on adsorption of the nascent chitin on to the celluloseester-filter matrix, is based on procedures used for DNA polymerase and hybridization studies (W. J. Harris, personal communication), and has proved more convenient than the chromatographic assay. The filters were placed in $4 \mathrm{ml}$ scintillation fluid containing $5 \mathrm{~g}$ 2,5-diphenyloxazole (PPO) and o.I g I 4-di-2-(5-phenyloxazolyl)-benzene (POPOP)/l toluene, and their radioactivity counted in a Packard Tricarb liquid scintillation counter. The counting efficiency was $79 \%$ as determined by the channels ratio method.

For all experiments, the specific activity of the enzyme was calculated from the percentage of radioactivity (c.p.m.) incorporated into chitin and was expressed as $\mathrm{nmol} \mathrm{N}$-acetylglucosamine incorporated $/ \mathrm{min} / \mathrm{mg}$ protein.

Determination of optimum conditions. The effect of temperature on enzyme activity was measured by using a particulate preparation (specific activity at $25^{\circ} \mathrm{C}$ of $57 \mathrm{nmol} / \mathrm{min} / \mathrm{mg}$ protein) and standard conditions. The effect of $\mathrm{pH}$ on enzyme activity was measured by using $0.05 \mathrm{M}$-TES-NaOH buffer [ $N$-tris-(hydroxymethyl)-methyl-2-amino-ethanesulphonic acid, from BDH]. Assays used a particulate preparation (specific activity $26 \mathrm{nmol}$ / $\min / \mathrm{mg}$ protein), and were otherwise done under standard conditions. 
Investigation of possible primer requirements. Soluble chitodextrin fractions were prepared by the controlled acid hydrolysis of chitin as described by Zechmeister \& Toth (I93I). Fraction II, precipitated by $95 \%$ ethanol, was used for all experiments. Wheat-germ agglutinin (WGA) was obtained from Calbiochem Ltd, San Diego, U.S.A., with a quoted agglutination titre of $\mathrm{I}: 32$ using $2 \%$ erthythrocytes. To test for possible incorporation of GlcNAc, substrates were $N$-[ $\left.{ }^{3} \mathrm{H}\right]$ acetyl-D-glucosamine $(243 \mathrm{mCi} / \mathrm{mmol})$ and $N$-acetyl$\left(\mathrm{I}-{ }^{14} \mathrm{C}\right) \mathrm{D}$-glucosamine $(57 \mathrm{mCi} / \mathrm{mmol})$, both from the Radiochemical Centre. The particulate enzyme preparation had a specific activity of $64 \mathrm{nmol} / \mathrm{min} / \mathrm{mg}$ protein in the standard assay. The incubations were at $25^{\circ} \mathrm{C}$ for $\mathrm{I} h$ in a final volume of $12.5 \mu \mathrm{l}$, at UDP-GlcNAc concentrations of $0,0.0 \mathrm{I}$, and $0.4 \mathrm{mM}$, in the presence of $500 \mathrm{nCi}\left[{ }^{3} \mathrm{H}\right] \mathrm{GlcNAc}(\mathrm{I} \mathrm{mM})$ or $5 \mathrm{nCi}$ $\left[{ }^{14} \mathrm{C}\right] \mathrm{GlcNAc}(0.04 \mathrm{~mm})$. Chitin synthetase activity was monitored by having assay tubes double-labelled with UDP- $N$-acetyl- $\left[{ }^{14} \mathrm{C}\right]$ glucosamine and $\left[{ }^{3} \mathrm{H}\right] \mathrm{GlcNAc}$. The reaction mixtures were chromatographed, autoradiographed, and radioactivities measured as usual.

Characterization of the enzyme product as chitin. Samples of enzyme reaction product, from particulate and solubilized preparations, were washed with water $(3 \times \mathrm{I} \mathrm{ml})$ by centrifugation ( $12000 \mathrm{~g}, r_{\mathrm{av} .} 47.5 \mathrm{~mm}$, for $2 \mathrm{~min}$; Eppendorf Microcentrifuge) to give about $10^{5}$ d.p.m., corresponding to about $5 \mu \mathrm{g}$ de novo product for each treatment. Some samples were incubated with I mg chitinase (Koch-Light) for $48 \mathrm{~h}$ at $25^{\circ} \mathrm{C}$, in a volume of $100 \mu \mathrm{l}$, with a drop of toluene added to prevent bacterial growth. The incubation mixtures were chromatographed with GIcNAc markers $\left(R_{F} 0.5 \mathrm{I}\right)$ on silica gel plates with propan-I-ol-water $(7: 3$, $\mathrm{v} / \mathrm{v})$, autoradiographed, and radioactive areas were removed and counted in scintillant. Others were hydrolysed with $6 \mathrm{M}-\mathrm{HCl}$, for $6 \mathrm{~h}$ at $100^{\circ} \mathrm{C}$, then dried, re-dissolved in water and chromatographed as above, with glucosamine markers $\left(R_{F} 0.12\right)$.

Samples were also reduced with $30 \mu \mathrm{l}$ fresh $0 . \mathrm{I} \mathrm{M}-\mathrm{KBH}_{4}$ for $15 \mathrm{~h}$ at $20{ }^{\circ} \mathrm{C}$, made to $6 \mathrm{M}-\mathrm{HCl}$ by the addition of conc. $\mathrm{HCl}$, and hydrolysed at $100^{\circ} \mathrm{C}$ for $6 \mathrm{~h}$. The tubes were dried in vacuo over $\mathrm{KOH}$ pellets and the products chromatographed on silica-gel thin-layer plates in butan-I-ol-acetic acid-water (5:4:I, by vol.), with markers of glucosamine $\left(R_{F} 0.29\right)$ and glucosaminitol $\left(R_{F} 0.19\right)$ prepared by the borohydride reduction and hydrolysis of GlcNAc. Any radioactive spots were scraped off and counted.

Products from incubations of the solubilized preparations were adsorbed on to Millipore filters as described above, to give about $10^{4}$ d.p.m. per filter, corresponding to about $\mathrm{I} \mu \mathrm{g}$ de novo product. Different filters were incubated in $\mathrm{I} \mathrm{ml}$ of the following reagents: I M-acetic acid at $25{ }^{\circ} \mathrm{C}$ for $\mathrm{Ig} \mathrm{h}$; $1 \mathrm{M}$-acetic acid at $95{ }^{\circ} \mathrm{C}$ for $30 \mathrm{~min}$; I M-hydrochloric acid at $25^{\circ} \mathrm{C}$ for $19 \mathrm{~h} ; 2 \mathrm{mg}$ trypsin in $0.05 \mathrm{M}$-potassium phosphate buffer $\mathrm{pH} 7.8$ at $25{ }^{\circ} \mathrm{C}$ for $\mathrm{I} 7 \mathrm{~h} ; 2 \mathrm{mg}$ chitinase in $0.05 \mathrm{M}$-potassium phosphate buffer $\mathrm{pH} 6.3$ at $25^{\circ} \mathrm{C}$ for $17 \mathrm{~h} ; 2 \mathrm{mg}$ chitinase (pre-treated in buffer at $95^{\circ} \mathrm{C}$ for $75 \mathrm{~min}$ ) at $25^{\circ} \mathrm{C}$ for $\mathrm{I} 7 \mathrm{~h}$. In each case the filters were then washed, dried, and their radioactivity counted.

Other nucleotide sugars as possible substrates. UDP-[U-14 C]D-glucose $(248 \mathrm{mCi} / \mathrm{mmol})$ and UDP-[U-14 $\mathrm{C}] \mathrm{D}$-galactose $(234 \mathrm{mCi} / \mathrm{mmol})$ were from The Radiochemical Centre, and GDP-[U-14 C]D-glucose ( $24 \mathrm{mCi} / \mathrm{mmol}$ ) was from International Chemical and Nuclear Corporation, Irvine, California, U.S.A. These were diluted to give $45 \mathrm{nCi}$ per assay with unlabelled nucleotide sugars from Sigma. They were incubated in a final volume of $12.5 \mu \mathrm{l}$ with $5 \mu \mathrm{l}$ particulate-enzyme preparation (specific activity for chitin synthesis $71 \mathrm{nmol} / \mathrm{min} /$ $\mathrm{mg}$ protein) for 5,30 and $60 \mathrm{~min}$ at $25^{\circ} \mathrm{C}$, in the presence of $0.05 \mathrm{M}$-tris- $\mathrm{HCl} \mathrm{pH} \mathrm{7.5,} 10 \mathrm{mM}-$ $\mathrm{MgCl}_{2}$ and I mM-EDTA (disodium salt). The reactions were stopped by immersion in a boiling-water bath for $2 \mathrm{~min}$. The mixtures were chromatographed, autoradiographed and radioactive products estimated as described for chitin synthetase.

Chromatography and autoradiography. Pre-spread silica gel F 254 and cellulose plates 


\section{Table I. The solubilization of chitin synthetase activity}

A microsomal pellet was resuspended in medium containing digitonin $(10 \mathrm{mg} / \mathrm{ml})$ at $0^{\circ} \mathrm{C}$ for $30 \mathrm{~min}$, and a sample assayed for enzyme activity. The remainder was centrifuged at $130600 \mathrm{~g}$ $\left(r_{\mathrm{av}}, 73 \mathrm{~mm}\right)$ for $\mathrm{I} \mathrm{h}$ and the supernatant and pellet (after resuspension in the same medium) were re-assayed.

\section{Sample}

Original microsomal preparation Solubilized preparation, supernatant Remaining pellet

$\begin{array}{ccc}\begin{array}{c}\text { Total protein } \\ (\mu \mathrm{g})\end{array} & \begin{array}{c}\text { Total activity } \\ (\mathrm{nmol} / \mathrm{min})\end{array} & \begin{array}{c}\text { Specific activity } \\ (\mathrm{nmol} / \mathrm{min} / \mathrm{mg} \text { protein) }\end{array} \\ 660 & 178 & 270 \\ 300 & 127 & 420 \\ 280 & 57 & 200\end{array}$

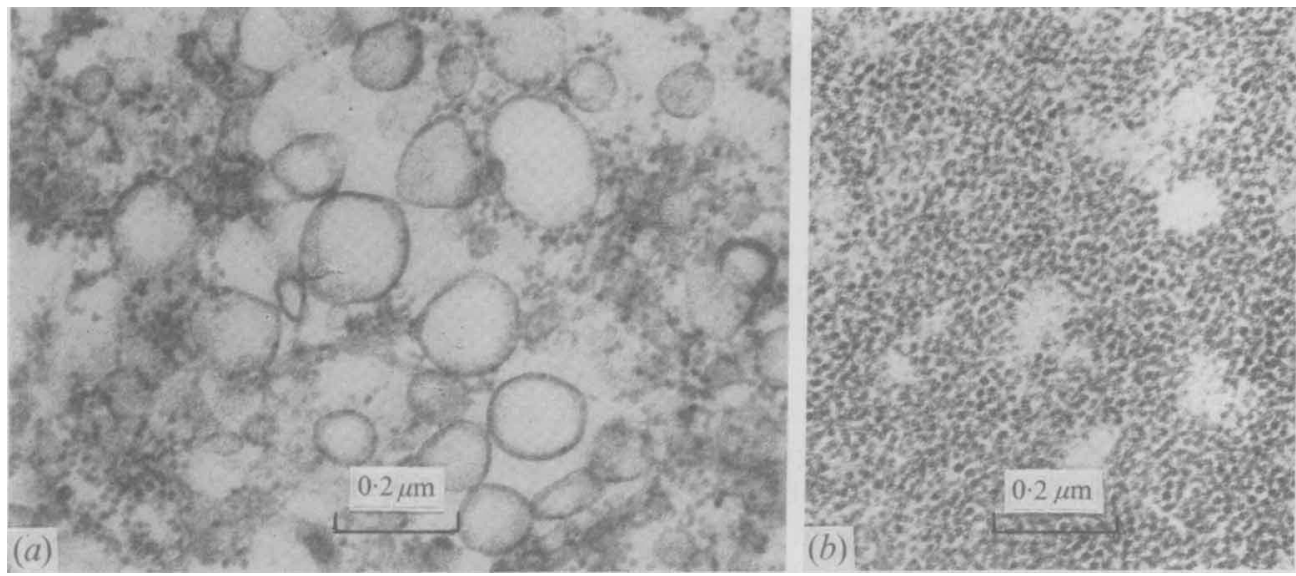

Fig. I. Electron micrographs of $(a)$ a microsomal pellet with chitin synthetase activity, and $(b)$ the pellet of particulate material remaining after digitonin treatment of a microsomal preparation. Pellets were prepared as described in Methods, then fixed with glutaraldehyde and $\mathrm{OsO}_{4}$, and stained with $2 \%(w / v)$ aqueous uranyl acetate at $60{ }^{\circ} \mathrm{C}$ for $20 \mathrm{~min}$ followed by Reynolds' lead citrate stain at $20^{\circ} \mathrm{C}$ for $7 \mathrm{~min}$.

(Merck) were used for the t.l.c. Radioactive spots were visualized by placing the plates in contact with Kodak Microtex X-ray film for at least $\mathrm{I} 2 \mathrm{~h}$. The film was developed for $5 \mathrm{~min}$ at $20^{\circ} \mathrm{C}$ with Kodak Di9 developer, washed for $0.5 \mathrm{~min}$ in $5 \%(\mathrm{v} / \mathrm{v})$ acetic acid and fixed for $2 \mathrm{~min}$ in Ilford Hypam fixer.

\section{RESULTS}

\section{Enzyme preparations}

The enzyme activity in tissue homogenates was highest in the microsomal fraction. All initial experiments used this particulate preparation. However, our later experiments have used a solubilized preparation and about $70 \%$ of the enzyme activity was released into the supernatant by using the method described. There was little change in the total activity following this treatment, but there was a significant increase in specific activity in the solubilized supernatant (Table I).

Electron micrographs of the microsomal pellet before digitonin treatment showed ribosomes interspersed with membrane fragments and vesicles (Fig. I $a$ ). There were a very few mitochondria in the preparation. The pellet formed after digitonin treatment consisted mainly of ribosomes, with few membrane fragments (Fig. I $b$ ). Negative staining of the supernatant failed to detect any membrane fragments or other particulate matter. The solubilized preparation of the enzyme was much more stable than the particulate 


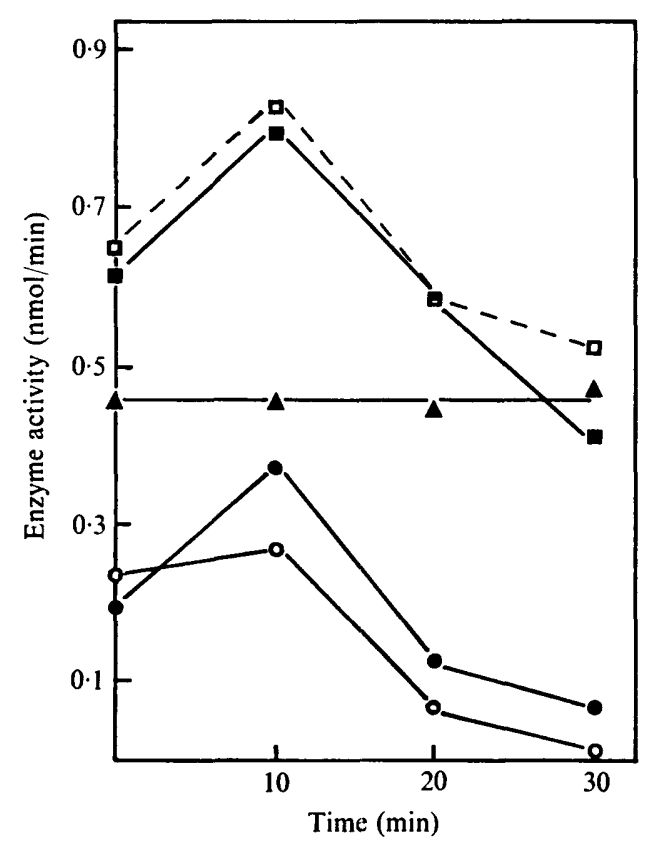

Fig. 2

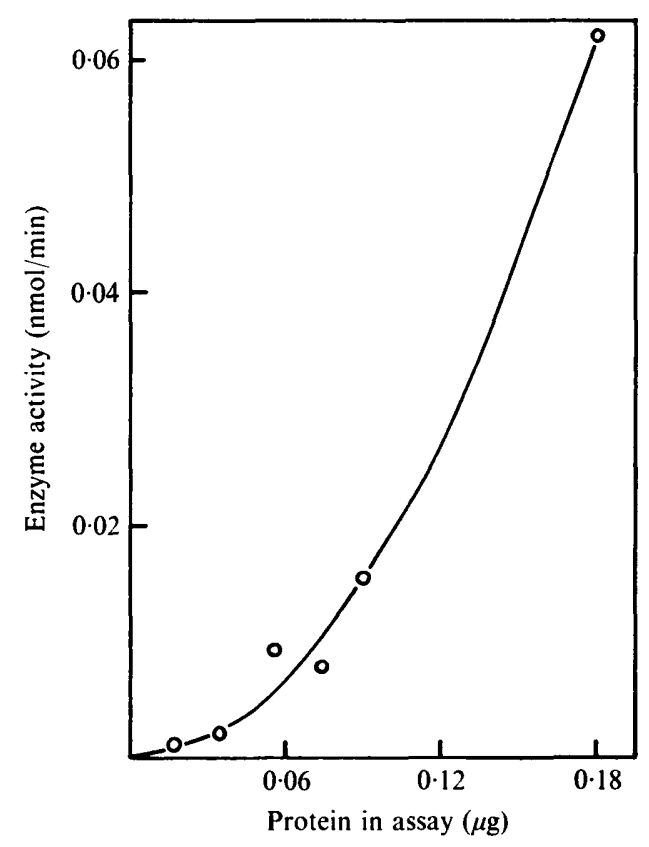

Fig. 3

Fig. 2. The effect of pre-incubating enzyme preparations at $25^{\circ} \mathrm{C}$ for various times before assay. $O$, Equal volumes of a particulate preparation and resuspending medium; $\boldsymbol{O}$, equal volumes of a particulate preparation and resuspending medium containing digitonin (IO $\mathrm{mg} / \mathrm{ml}) ; \Delta$, equal volumes of a digitonin-solubilized preparation and resuspending medium; $\mathbf{v}$, equal volumes of the particulate and the digitonin-solubilized preparations; $\square$, calculated values (by addition of activities found for the particulate and solubilized preparations assayed separately). All assays were for $5 \mathrm{~min}$ at $25^{\circ} \mathrm{C}$, with I mM-UDP-GlcNAc, in a final volume of $20 \mu \mathrm{l}$, and all except the first in the presence of digitonin at a final concentration of $1.25 \mathrm{mg} / \mathrm{ml}$.

Fig. 3. Effect of protein concentration in the assay on enzyme activity of a solubilized preparation, showing non-linearity at very low concentrations. Routine assays always used more than $\mathrm{I} \mu \mathrm{g}$ protein in the assay volume of $20 \mu \mathrm{l}$ (see Methods). At higher protein concentrations the enzyme activity increased as a linear extrapolation of this graph up to $4 \mu \mathrm{g}$ protein/assay. The very low incorporations shown here were measured by using longer counting times than usual.

preparation. The particulate preparation lost $50 \%$ of its activity either after storage at $-20^{\circ} \mathrm{C}$ for 7 days, or within $20 \mathrm{~min}$ at $25^{\circ} \mathrm{C}$. The solubilized preparation showed no loss of activity after 5 weeks at $-20^{\circ} \mathrm{C}$, and it retained $80 \%$ of its activity after $2 \mathrm{~h}$ at $25^{\circ} \mathrm{C}$. The addition of bovine serum albumin (to $10 \mathrm{mg} / \mathrm{ml}$ ), glycerol (to $25 \%, \mathrm{v} / \mathrm{v}$ ), or dithiothreitol (to $400 \mu \mathrm{M}$ ) had no stabilizing effect on the particulate preparation at $25^{\circ} \mathrm{C}$. The addition of digitonin to a particulate preparation at $25^{\circ} \mathrm{C}$ resulted in some increase in activity but did not prevent a subsequent rapid loss of activity. The results of one experiment, showing a transient $90 \%$ increase, are shown in Fig. 2. If a solubilized preparation was added to a particulate preparation and the resultant mixture assayed, the enzyme activity was equivalent to the sum of the two separate activities (Fig. 2). There was no inhibition, which might be expected if the inactivation of the particulate preparation was caused by release of an inhibitor, and there was no apparent stabilization of the particulate activity.

The experiments using particulate preparations were chiefly assayed by t.l.c. of the reaction products. In all assays the only radioactive spots were the mobile substrate 
UDP-GlcNAc and the chitin on the origin. The reproducibility of the assays was routinely checked, a typical result being a standard deviation of 19 from a mean value of $238 \mathrm{nmol} /$ $\mathrm{min} / \mathrm{mg}$ protein for ten assays of a solubilized preparation.

\section{Optimum conditions for enzyme activity}

The temperature optimum was $30{ }^{\circ} \mathrm{C}$ for a 5 min assay of a particulate preparation. The standard temperature of $25{ }^{\circ} \mathrm{C}$ gave $96 \%$ of maximal activity. Half the maximal activity was obtained at $9{ }^{\circ} \mathrm{C}$ and $43{ }^{\circ} \mathrm{C}$, and $25 \%$ at $0{ }^{\circ} \mathrm{C}$ and $48{ }^{\circ} \mathrm{C}$. The $\mathrm{pH}$ optimum of a particulate preparation was $8 \cdot 0$.

The effect of enzyme protein concentration was tested by assays ( $5 \mathrm{~min}$, with I mM-UDPGlcNAc, at $25^{\circ} \mathrm{C}$ ) with serial dilutions of a particulate preparation in the resuspending medium. The rate of chitin formation was linear between 0 and $24 \mu \mathrm{g}$ protein in the assay volume of $20 \mu \mathrm{l}$. The experiment was repeated with a solubilized preparation that had been concentrated by dialysis in a Minicon A-25 solution (Amicon Ltd, Oosterhoot, The Netherlands). Serial dilutions were made with resuspending medium with or without digitonin ( $10 \mathrm{mg} / \mathrm{ml}$ ), and assays were performed as before. The rate of chitin formation was linear between $0 \cdot \mathrm{I}$ and $4 \mu \mathrm{g}$ protein in the assay volume of $20 \mu \mathrm{l}$, but extrapolation to zero activity gave an intercept on the abscissa. Assays with protein below $0.1 \mu \mathrm{g}$ gave a non-linear plot (Fig. 3). Results were the same in the presence and absence of digitonin in the diluent, and so this substance appears to have no direct effect on enzyme activity. Routine assays with the solubilized preparation in other experiments always used betwean I and $2 \mu \mathrm{g}$ protein per assay.

With the particulate and solubilized preparations, the rate of chitin formation was linear with time for at least $5 \mathrm{~min}$, and usually for up to $10 \mathrm{~min}$, with both high (I $\mathrm{mm}$ ) and low (0.05 mM) UDP-GlcNAc concentrations. After this time the enzyme activity declined, probably partially owing to a build-up of uridine diphosphate which is an inhibitor of our enzyme preparation (de Rousset-Hall \& Gooday, 1975).

\section{Requirements for enzyme activity}

Our enzyme preparations have only two essential requirements for chitin synthesis: uridine diphosphate- $N$-acetylglucosamine as the glycosyl donor; and a divalent metal cation, supplied as $\mathrm{Mg}^{2+}$, as co-substrate (A. de Rousset-Hall, G. W. Gooday and K. W. Knox, unpublished). The enzyme activity must be written thus:

$$
(\text { GlcNAc })_{n}+\text { UD-GlcNAPc } \rightarrow(\text { GlcNAc })_{n+1}+\text { UDP. }
$$

However, we have no evidence as to the nature of the acceptor or 'primer'. The addition of chitodextrins ( $\mathrm{N}$-acetylglucosamine oligomers) to both the particulate and the solubilized enzyme preparations gave very little stimulation in activity. Some typical results are shown in Table 2. A much greater stimulation, or even an absolute requirement, would be expected if the chitodextrins were glycosyl acceptors in the reaction.

It is possible that there are abundant free chitin fragments to act as primers in the particulate enzyme preparation, but this seems unlikely in the solubilized preparation, unless they are released by the digitonin treatment and not sedimented by centrifugation. As the rationale of the cellulose-ester-filter assay was that the filter would adsorb the nascent chitin chains, such a filtration might remove any free chitin fragments in the enzyme preparation. However, there was no change in the specific activity of a solubilized preparation after filtration through a $0 \cdot 22-\mu \mathrm{m}$-pore Millipore GS filter.

In a similar experiment a solubilized enzyme preparation was pre-incubated for $6 \mathrm{~min}$ 
Table 2. Effect of soluble chitodextrins on chitin synthetase activity

\begin{tabular}{|c|c|c|c|}
\hline \multirow[b]{2}{*}{ Enzyme conditions* } & \multicolumn{2}{|c|}{ Enzyme activities (nmol/min/mg protein) } & \multirow{2}{*}{$\begin{array}{c}\text { Stimulation } \\
(\%)\end{array}$} \\
\hline & Control & Plus chitodextrins $(2 \mathrm{mg} / \mathrm{ml})$ & \\
\hline $\begin{array}{l}\text { Particulate preparation } \\
\text { 0.4 mM-UDP-GIcNAc, } 10 \mathrm{mM}- \\
\text { GlcNAc }\end{array}$ & 55.5 & $66 \cdot 6$ & 20 \\
\hline $\begin{array}{l}\text { Solubilized preparation } \\
\text { O.I mM-UDP-GlcNAc } \\
\text { I.0 mM-UDP-GlcNAc }\end{array}$ & $325^{7 \cdot 0}$ & $365^{9.4}$ & $\begin{array}{l}34 \\
12\end{array}$ \\
\hline
\end{tabular}

Table 3. The effect of wheat-germ agglutinin (WGA) on chitin synthetase activity

Final concn of WGA $(\mu \mathrm{g} / \mathrm{ml})$

Percentage of control activity*

$\begin{array}{rrrrrr}0 & \text { I } & 10 & 100 & 1000 & 10000 \\ 100 & 98 & 87 & 45 & 16 & 83\end{array}$

* Control activity was $167 \mathrm{nmol} \mathrm{GlcNAc}$ incorporated $/ \mathrm{min} / \mathrm{mg}$ protein.

at $25{ }^{\circ} \mathrm{C}$ with varying concentrations of WGA and then assayed for enzyme activity. The WGA might bind to any accessible $\mathrm{N}$-acetylglucosamine residues in the enzyme preparation and so mask any such primers. The results (Table 3 ) do indicate some inhibition of enzyme activity, but not the total inhibition that might be expected if the primer was removed from the enzyme reaction, and they probably reflect inhibition due to binding of the nascent chitin chains.

$\mathrm{N}$-acetylglucosamine activates the Coprinus chitin synthetase preparations and this phenomenon is examined in detail elsewhere (de Rousset-Hall \& Gooday, I975). However, the possibility that this monomer of chitin could be incorporated into our enzyme product had to be investigated, as it could be suggested that it activates by being a primer or by being inserted along the growing chain. In no experiment, with a range of conditions, using either ${ }^{14} \mathrm{C}$ - or ${ }^{3} \mathrm{H}$-labelled $\mathrm{N}$-acetylglucosamine, has there been any evidence for incorporation of this sugar into the chromatographically immobile product, and it has always been recovered unchanged from the thin-layer chromatograms.

\section{Characterization of the reaction product}

The enzyme product had the following properties in common with chemically purified chitin: (i) it is chromatographically immobile in a wide range of solvents on silica gel and cellulose thin-layer chromatograms and on paper; (ii) incubating it with chitinase for $48 \mathrm{~h}$ at $25{ }^{\circ} \mathrm{C}$ gives total degradation to $N$-acetylglucosamine (N.B. this preparation of 'chitinase', EC. 3.2.I.I4, must also have activity to degrade diacetyl-chitobiose, the strict product of chitinase, to the monomer); (iii) it can be centrifuged from aqueous suspensions to form a pellet; (iv) the resulting pellet is soluble in conc. $\mathrm{HCl}$ at $0^{\circ} \mathrm{C}$ but insoluble in $\mathrm{I} \mathrm{M-KOH}$ $\left(\mathrm{I} \mathrm{h}, 100^{\circ} \mathrm{C}\right)$; (v) it is hydrolysed completely to glucosamine by $6 \mathrm{M}-\mathrm{HCl}\left(6 \mathrm{~h}, 100{ }^{\circ} \mathrm{C}\right)$. No reduction in radioactivity was found when filters with the bound radioactive product of the solubilized enzyme preparation were treated with dilute mineral acids, trypsin or boiled chitinase. However, the radioactivity was almost completely removed after treatment of the filter with chitinase.

Further characterization of the radioactive reaction product was accomplished by reducing it with potassium borohydride followed by hydrolysis. The only radioactive product was 
chromatographically identical with glucosamine and no radioactive glucosaminitol was detected. Thus there were no radioactive reducing end groups in the enzyme product detectable by this technique.

\section{Other nucleotide sugars as possible substrates}

The particulate enzyme preparation was incubated with other nucleotide sugars under a range of conditions to determine whether it had glycosyl transferase activity. The possible substrates were uridine diphosphate $\left[\mathrm{U}-{ }^{14} \mathrm{C}\right]$ glucose, uridine diphosphate $\left[\mathrm{U}-{ }^{14} \mathrm{C}\right]$ galactose and guanosine diphosphate $\left[\mathrm{U}-{ }^{14} \mathrm{C}\right]$ glucose, at concentrations of 0.02 and $2.5 \mathrm{mM}$, with and without the addition of $0.4 \mathrm{mM}-U D P-N$-acetylglucosamine. In no case was a chromatographically immobile product formed, and so the preparation had no glucan or galactan synthetase activity in these conditions. However, the nucleotide sugars were metabolized to give some other products after I $h$. For example, $0.02 \mathrm{~mm}$-UDP-glucose gave a radioactive product chromatographically corresponding to glucose, and three unknown products, one of them with a chromatographic mobility suggesting a glycolipid.

\section{DISCUSSION}

The Coprinus fruit body appears to be a particularly rich source of chitin synthetase activity. The specific activities in our preparations are much larger than any previously reported. The morphogenetic role of this enzyme activity during development of the fruit body is strongly suggested by the report that the activity determined in vitro is sufficient to give the increase in chitin observed in vivo (Gooday, 1973).

Our results favour the conclusion that the enzyme product consists of long-chain chitin molecules. Diacetylchitobiose and other short-chain oligomers of $\mathrm{N}$-acetylglucosamine have never been observed as products, although they would either be seen in t.l.c. assays or, if bound at the origin of the t.l.c. plate, give glucosaminitol after reduction and hydrolysis. A wide range of conditions have been monitored for their formation, such as low substrate concentrations that favour biose formation by a $\beta$-I,3-glucan synthetase (Kemp \& Loughman, 1974), and high $N$-acetylglucosamine concentrations that favour diacetylchitobiose formation in enzyme preparations from Mucor rouxii (McMurrough \& Bartnicki-Garcia, 1971). However, diacetylchitobiose could arise if an enzyme preparation contained chitinase activity and this may explain some of the reports of this being a product.

Digitonin has also been used successfully to solubilize $\beta$-I,3-glucan synthetase from Phaseolus aureus (Flowers et al. 1968). We assume that it acts partly as a detergent and partly by complexing with membrane sterols. Glaser \& Brown (1957) report that digitonin inactivated the chitin synthetase from Neurospora crassa, but they did obtain some solubilization of activity by treating their microsomal preparations with butan-I-ol. The term 'solubilized' for our preparation is used for convenience and not to imply the exact physical state of the enzyme molecules, which is still being investigated. Ruiz-Herrera \& Bartnicki-Garcia (1974) have reported solubilization of chitin synthetase from $M$. rouxii by pre-incubation with UDP-GlcNAc and GlcNAc. The particulate and solubilized preparations from Coprinus have been qualitatively identical in all the properties studied here, except that the solubilized preparation is much more stable.

All of our assays have been done without knowing the concentration of one of the two reactants in the reaction equation - the primer or acceptor-but our results strongly suggest that it cannot be limiting. For a detailed kinetic study of the effect of UDP-GlcNAc concentration, see de Rousset-Hall \& Gooday (1975). Attempts to add possible primers in the form of chitodextrins to the Coprinus preparations have resulted in small increases in 
enzyme activity, in contrast to the reports from other systems, such as Venturia inaequalis (Jaworski, Wang \& Carpenter, 1965), Allomyces macrogynus (Porter \& Jaworski, 1966) and $N$. crassa, where the butanol-solubilized enzyme had a requirement for added chitodextrins. However, although Glaser \& Brown (1957) did show some incorporation of radioactive chitodextrins into the enzyme product from $N$. crassa, these oligomers may also be activating as $N$-acetylglucosamine and diacetylchitobiose do, without being incorporated. As we were unable to remove any primer from our enzyme preparations, it would appear that before and after digitonin treatment the enzyme molecules carry sufficient primer firmly bound to them.

We thank the Agricultural Research Council for financial assistance (grant AG I/24).

\section{REFERENCES}

Flowers, H. M., Batra, K. K., KemP, J. \& Hassid, W. Z. (1968). Biosynthesis of insoluble glucans from Phaseolus aureus and Lupinus albus. Plant Physiology 43, 1703-1709.

Glaser, L. \& BRown, D. H. (1957). The synthesis of chitin in cell-free extracts of Neurospora crassa. Journal of Biological Chemistry 228, 729-742.

Gooday, G. W. (1972a). The effect of polyoxin D on morphogenesis in Coprinus cinereus. Biochemical Journal r29, 17-18P.

GoodAy, G. W. $(1972 b)$. The role of chitin synthetase in the elongation of fruit bodies of Coprinus cinereus. Journal of General Microbiology 73, xxi.

Gooday, G. W. (1973). Activity of chitin synthetase during the development of fruit bodies of the toadstool Coprinus cinereus. Biochemical Society Transactions 1, I 105-1 107.

GoodAy, G. W. (1974). Control of development of excised fruit bodies and stipes of Coprinus cinereus. Transactions of the British Mycological Society 62, 391-399.

JAWORSKI, E. G., WANG, L. C. \& CARPENTER, W. D. (1965). Biosynthesis of chitin in cell-free extracts of Venturia inaequalis. Phytopathology 55, I309-I3I 2.

Kemp, J. \& Loughman, B. C. (1974). Cyclitol glucosides and their role in the synthesis of a glucan from uridine diphosphate glucose in Phaseolus aureus. Biochemical Journal 142, I53-159.

Lowry, D. H., Rosebrough, N. J., Farr, A. L. \& Randall, R. J. (I95I). Protein measurement with the Folin phenol reagent. Journal of Biological Chemistry 193, 265-275.

McMurrough, I. \& Bartnicki-Garcia, S. (197I). Properties of a particulate chitin synthetase from Mucor rouxii. Journal of Biological Chemistry 246, 4008-40I6.

PorTer, C. A. \& JAWORSKI, E. G. (1966). The synthesis of chitin by particulate preparations of Allomyces macrogynus. Biochemistry 5, II 49-I I 54.

De Rousset-Hall, A. \& Gooday, G. W. (1975). A kinetic study of a solubilized chitin synthetase preparation from Coprinus cinereus. Journal of General Microbiology 89, 146-154.

Ruiz-Herrera, J. \& Bartnicki-Garcia, S. (1974). Synthesis of cell wall microfibrils in vitro by a soluble chitin synthetase from Mucro rouxii. Science, New York 186, 357-359.

ZeChmeister, L. \& Toth, G. (1931). Zur Kenntnis der Hydrolyse von Chitin mit Salzsäure. Berichte der Deutschen chemischen Gesellschaft 64, 2028-2031. 